Portland State University

PDXScholar

Engineering and Technology Management

Faculty Publications and Presentations

$10-8-2018$

\title{
Technology Planning for Aligning Emerging Business Models and Regulatory Structures - The Case of Electric Vehicle Charging and the Smart Grid
}

Kelly Cowan

Portland State University

Tugrul Daim

Portland State University, tugrul@etm.pdx.edu

Follow this and additional works at: https://pdxscholar.library.pdx.edu/etm_fac

Part of the Engineering Commons

Let us know how access to this document benefits you.

\section{Citation Details}

K. Cowan and T. U. Daim, "Technology Planning for Aligning Emerging Business Models and Regulatory Structures - The Case of Electric Vehicle Charging and the Smart Grid," 2018 Portland International Conference on Management of Engineering and Technology (PICMET), Honolulu, HI, 2018, pp. 1-10.

This Article is brought to you for free and open access. It has been accepted for inclusion in Engineering and Technology Management Faculty Publications and Presentations by an authorized administrator of PDXScholar. Please contact us if we can make this document more accessible: pdxscholar@pdx.edu. 


\title{
Technology Planning for Aligning Emerging Business Models and Regulatory Structures -
}

\author{
The Case of Electric Vehicle Charging and the Smart Grid
}

\author{
Kelly Cowan, Tugrul U. Daim \\ Dept. of Engineering \& Technology Management, Portland State University, Portland, OR, USA
}

\begin{abstract}
Smart Grid has the potential to produce over \$2 trillion of benefits in the US utility sector over the next 20 years, according to a study by the Electric Power Research Institute. However, the study also projects significant costs of up to $\$ 476$ billion to achieve these returns. Therefore, while smart grid represents an enormous opportunity, with a benefit-to-cost ratio of nearly 6 to 1, given the enormous financial sums at stake, it is crucial that the planning process for smart grid be done with extreme care. Planning the deployment of smart grid technology in the electric utility sector can be a complex and difficult process due to regulatory frameworks that have evolved to protect consumers, the need for development of standards regarding numerous emerging technologies, and the need for emerging business models which can fit with these evolving technology and regulatory frameworks. Technology roadmapping provides a number of useful tools which can help with the planning of smart grid development, but a highly integrated approach is needed to accommodate the full range of factors mentioned.
\end{abstract}

\section{MOTIVATION \& OVERVIEW OF LITERATURE}

Power grid modernization offers the opportunity to implement technologies that offer both revolutionary new capabilities and absolutely essential support function to allow the electrical backbone that modern technological society depends upon to continue functioning in a reliable and efficient manner. This research examines the case of smart grid technologies related to electric vehicle charging and provides a model for considering key technology, regulatory, and business factors with an emphasis on unique challenges in the Pacific Northwest. To conduct this research, it was necessary to perform an industry analysis, regulatory and policy analysis, an examination of the technology landscape, and to look at existing and emerging business models. Key factors were then prioritized to understand how they contributed to specific goals. A taxonomy was also created to organize business models and tools were created for more easily comparing them and seeing how they related to roadmap elements.

Literature from several key literature streams was reviewed for this paper and research gaps were identified. The first stream analyzed was the Technology Roadmapping literature (TRM). The following research gaps are summarized on the table in Figure 1.

A number of processes have been developed for applying TRM to current and emerging industries. General methods have been created for examining both the strategic landscape and technology performance characteristics of new technology product development [1-5]. Application of such processes to disruptive technologies is highly relevant for smart grid and has been well examined in the literature [6-15]. The process has also been applied to emerging technologies in the renewable and sustainable energy industry, which have strong overlaps with and similarities to the smart grid industry [16-25].

\begin{tabular}{|c|c|c|}
\hline Research Concept & References & Research Gaps \\
\hline $\begin{array}{l}\text { Various processes } \\
\text { developed for applying } \\
\text { TRM in current and } \\
\text { emerging industries } \\
\quad \text { Several methods } \\
\text { integrate aspects of } \\
\text { business modeling with } \\
\text { TRM } \\
\quad \text { Few studies consider } \\
\text { policy dimensions of TRM } \\
\text { or regulatory frameworks, } \\
\text { particularly in the utility } \\
\text { industry } \\
\quad \text { TRM generally used at } \\
\text { company-, industry-, and } \\
\text { national-level, rather than } \\
\text { incorporating regional } \\
\text { utility concerns } \\
\quad \text { More work also } \\
\text { needed prioritizing R\&D, } \\
\text { acquisition, and barriers }\end{array}$ & $\begin{array}{l}{[18,19],[21,22],[26-31],} \\
{[32-36],[37-50],[51,52]} \\
{[53,54],[32],[34],[37]}\end{array}$ & $\begin{array}{l}\quad \text { Method is needed } \\
\text { to integrate business } \\
\text { modeling, policy, and } \\
\text { regulatory factors into } \\
\text { TRM for the utility } \\
\text { industry } \\
\qquad \text { TRM goals must } \\
\text { align with regional- } \\
\text { level factors for utility } \\
\text { industry and associated } \\
\text { products } \\
\qquad \\
\quad \text { Additional work } \\
\text { needed prioritizing } \\
\text { R\&D, acquisition } \\
\text { processes, and barriers } \\
\text { in utility related } \\
\text { industries }\end{array}$ \\
\hline
\end{tabular}

Fig. 1. Technology Roadmapping Literature Gaps

However, the customization of such processes to meet the needs of specific industries, business models, and emerging technology products is an important need that must be addressed. A variety of methods have been developed for integrating aspects of business modeling with technology roadmapping [18, 19], [21, 22], [26-31]. The application of roadmapping to smart grid related industries also need to consider regional implications associated with region spanning utility systems [32-36] and development of business models to address strategic, regulatory, and policy landscapes [37-52].

Few studies, however, have done detailed analysis of the policy dimensions of TRM or regulatory frameworks, particularly with regard to the utility industry [53, 54], [32], [34], [37]. TRM has generally been done at company-, industry-, and national-level, rather than incorporating regional utility concerns [55-63] [53, 54, 64-67]. More work is also needed to understand how to prioritize R\&D needs, acquisition efforts [68-75] as well as to understand barriers what may affect implementation. It then may be possible to determine how such barriers could be mitigated with practices involving 
appropriate business models, market, and regulatory elements [31-43].

Therefore, a method is needed to integrate business modeling, policy, and regulatory factors into TRM for the utility industry. This method is particularly important for the utility industry, due to it unique characteristics and the need for regional scale solutions. Additional research is also needed regarding prioritization of $\mathrm{R} \& \mathrm{D}$ acquisition processes, and barriers in utility related industries. An improved methodology could provide a more complete and better integrated smart grid roadmap to improve planning in the industry. Without such a method, technology planning for regional scale utility systems is likely to be slower, more difficult, and less integrated.

The second key area analyzed in this research was the Smart Grid and Electric Vehicle literature. The initial discussion of this included only general literature. The following research gaps are summarized on the table below.

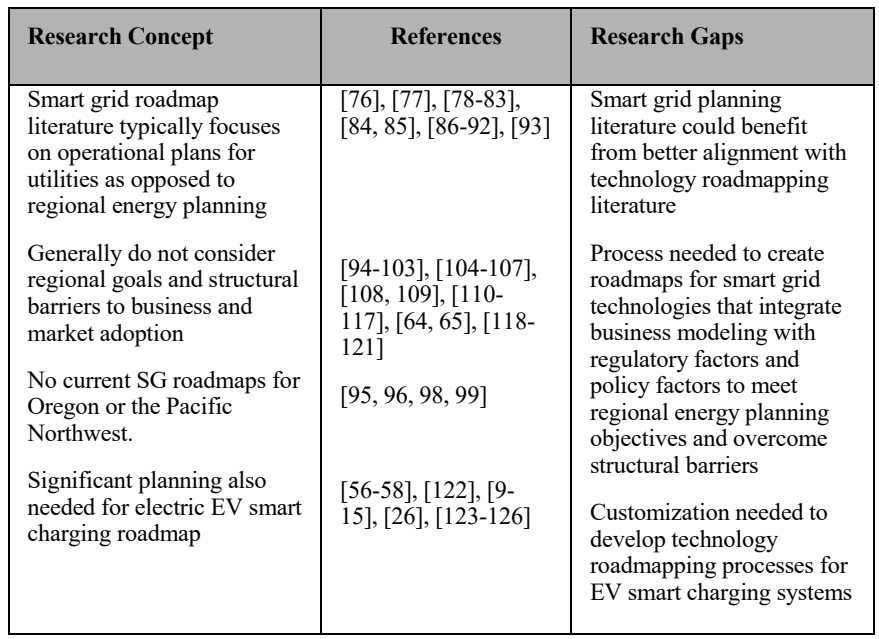

Fig. 2. Smart Grid \& Electric Vehicle Literature Gaps

Smart grid roadmap literature typically focuses on operational plans [76], [77], [78], [79-83], for utilities as opposed to regional energy planning [86-92]. Some studies examined limited aspects of wider regional planning and generally indicated advantages over more narrow operational plans $[84,85,93]$.

However, most current studies examined to date generally have not emphasized regional level considerations [94-107, 127-129\{Cowan, 2007 \#337\}]. Research on important elements of regional level smart grid planning has been initiated [108-117]. But, these results have not generally been integrated into models that systematically consider and assess regional goals [64, 65, 118-121]. Process needed to create roadmaps for smart grid technologies that integrate business modeling with regulatory factors and policy factors to meet regional energy planning objectives and overcome structural barriers.

Although some initial state-level studies have been conducted, no current smart grid roadmaps have been created for Oregon or the Pacific Northwest on a regional basis [95, 96, 98, 99]. Supporting important goals like the Renewable Portfolio Standard in Oregon and most other Northwestern states has been discussed in chapter 3, along with smart appliances, such as electric vehicles. Electric Vehicle Smart Charging technologies appear to offer significant potential to support key state and regional goals for meeting the portfolio standard and enhancing to robustness of the power system. However, significant planning efforts [56-58] are needed to created roadmaps related to these emerging technologies [122], [9-15], [26] and adapt them to the needs business and market, policy and regulatory, and technology needs that have been discussed for such a system [123-126].

Processes are needed to create roadmaps for smart grid technologies that integrate business modeling with regulatory factors and policy factors to meet regional energy planning objectives and overcome structural barriers. Smart grid planning literature could benefit from better alignment with technology roadmapping literature. But, significant customization is needed to develop roadmapping processes for EV Smart Charging Systems.

The third key area discussed was the Resource Planning literature. The initial discussion of this included only general literature. The following research gaps are summarized on the table below.

\begin{tabular}{|c|c|c|}
\hline Research Concept & References & Research Gaps \\
\hline $\begin{array}{l}\text { Strategic alignment of } \\
\text { business model and policy } \\
\text { frameworks particularly } \\
\text { important for regulated } \\
\text { industries like electric utilities }\end{array}$ & $\begin{array}{l}{[130],[131],[132],} \\
{[133-139],[84,85,} \\
94-97],[101],[88, \\
89],[110-114],[118], \\
{[140,141]}\end{array}$ & $\begin{array}{l}\text { Need to incorporate an } \\
\text { understanding of utility } \\
\text { regulation and planning } \\
\text { processes to create } \\
\text { strategic alignment } \\
\text { between business models } \\
\text { and policy frameworks }\end{array}$ \\
\hline $\begin{array}{l}\text { Unique regional energy policy } \\
\text { planning issues in Pacific } \\
\text { Northwest due to regulatory } \\
\text { frameworks }\end{array}$ & $\begin{array}{l}{[98-100,102],[92],} \\
{[108,109],[61,62,} \\
115],[32-34],[120]\end{array}$ & $\begin{array}{l}\text { TRM methods need to be } \\
\text { adapted to unique } \\
\text { regulatory frameworks for } \\
\text { regional utility industries }\end{array}$ \\
\hline $\begin{array}{l}\text { Multiple perspectives view is } \\
\text { critical for creating robust } \\
\text { planning models in the utility } \\
\text { industry }\end{array}$ & $\begin{array}{l}{[1-3],[56-58],[69-} \\
74],[142,143]\end{array}$ & $\begin{array}{l}\text { Strong need for multiple } \\
\text { perspective planning } \\
\text { models in utility industry } \\
\text { that create strategic } \\
\text { alignment between } \\
\text { business models, policy, } \\
\text { and regulatory } \\
\text { requirements }\end{array}$ \\
\hline
\end{tabular}

Fig. 3. Resource Planning \& Policy Literature Gaps

Strategic alignment of business model and policy frameworks is particularly important for regulated industries like electric utilities [130], [131], [132], [133-135]. As discussed in chapter 1, utilities generally have large capital costs, high barriers to entry, and increasing efficiencies of scale. This gives them many characteristics of natural monopolies. Traditional structures present a number of advantages and disadvantages. But, with rapid technology advances in the utility sector, one key issue is the need to overcome chronically low levels of R\&D investment in the industry, estimated at around $0.25 \%$ of revenues [136]. There is also a need to understand that many aspects of utility regulatory structures have been useful and durable [137-139]. Thus, it is necessary to incorporate an understanding of utility regulation and planning processes [84, 85, 94-97] to create alignment [110-114] between business models and policy 
frameworks [118], [140, 141], and technology development [101], [88, 89].

In particular, unique energy policy planning issues exist in Pacific Northwest due to multiple regulatory frameworks at the state [98-100, 102], federal [92, 108, 109], and regional [61, $62,115]$ levels. Implementing improved smart grid roadmaps will take considerable amounts of discipline spanning knowledge [32-34], [120]. A multiple perspectives view [69$74]$ is critical for creating robust planning models in the utility industry [56-58], [142, 143] and incorporate these inputs into a roadmapping process that an understanding of utility regulation and planning processes to create strategic alignment between business models and policy frameworks. TRM methods need to be adapted to unique regulatory frameworks for regional utility industries [1-3]. Overall, there is a strong need for robust, multiple perspective planning models in the utility industry that create strategic alignment between business models, policy, and regulatory requirements.

This section has explained how the gaps identified in this research area are driven by the practical needs to better understand the costs and benefits of smart grid technology and to better plan its implementation. The next section of this research provides a set of tools designed to assist with the roadmap development and prioritization process. A series of data collection instruments, matrixes, and prioritization tools are presented to perform various stages of roadmap construction and assessment of the various input factors.

\section{EXPERT DATA}

To conduct this research, two expert panels that were assembled consisting of five management-level professionals with at least five years of experience and a degree in a relevant discipline to the research topic being discussed. The first expert panel was comprised of managers, executives, and decision makers in the utility industry, as well as energy policy analysts familiar with the regional issues. It was tasked with identifying drivers, gaps, goals, and barriers for the development of electric vehicle smart charging and vehicle-togrid systems. The second expert panel was comprised of executives, business leaders, and experts from the electric vehicle and vehicle charging industries. It was tasked with analyzing the industry and identifying gaps in technologies and business models needed to satisfy customer and stakeholder needs, as well as identifying potential solutions to satisfy these needs. The members of each panel were also selected to provide balance and to represent a range of viewpoints. The goal of the panel was to span multiple industries and disciplines to achieve a cross section designed to eliminate bias.

The first tool shown below provides a means of grouping data related to market and business drivers. Experts were asked to rate the general priority level of each of these drivers based on their views of its overall future impact on the market. Each driver is assigned a unique code and described in Appendix E of the full research study, along with each other roadmap element. Grouped driver are shown below.
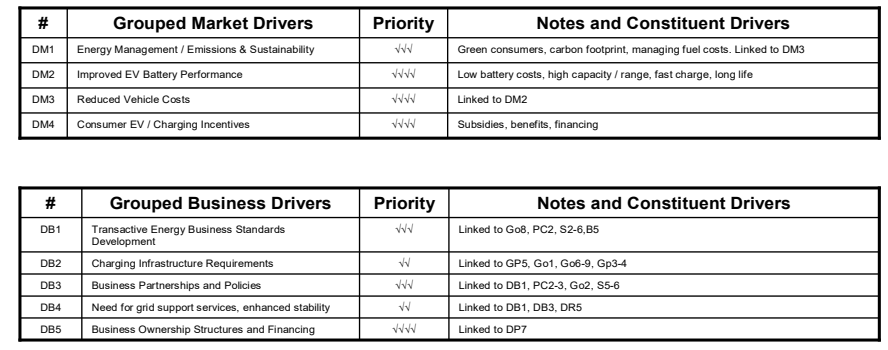

Figure 4: Grouped Drivers - Market and Business

The second tool, shown below, is another basic data gathering form used for collecting and grouping information related to regulatory and policy drivers. Expert are also asked to rate the general priority level of each of these drivers based on their views of it overall future impact of specific regulatory structure or policy initiatives regarding the development of the industry and related technology products. This is shown below.

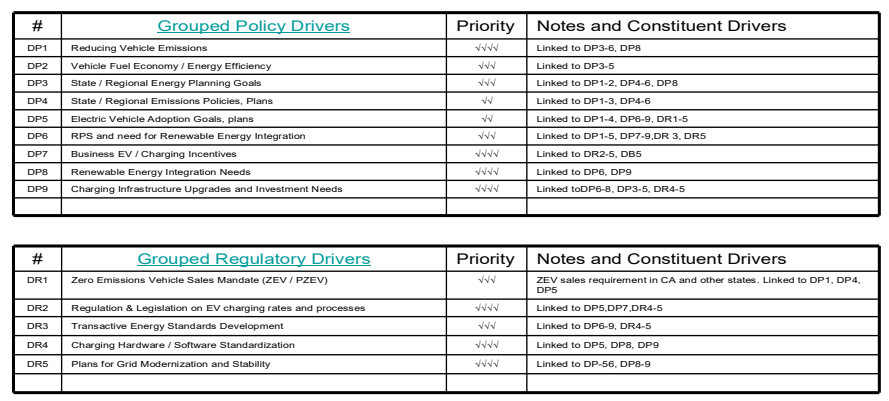

Figure 5: Grouped Drivers - Regulatory and Policy

\section{TECHNOLOGY RoAdMAP MOdEL}

After finishing the initial data gathering and prioritization processes, a series of roadmap models were constructed incorporating the data. Several types of roadmaps were created to examine different aspects of this research. First, an overall roadmap was created that showed the combined effect of business, government, consumer, and market factors over the entire 10-year time span of the roadmap. This roadmap is consists of three parts, representing different set of layers on the roadmap. Part 1 is composed of three layers: (1) Drivers; (2) Gaps and Goals; and (3) Problem Characteristics and Barriers. Part 2 contains two layers: (1) a continuation of Problem Characteristics and Barriers; and (2) Solutions, which involve Technology, Business Model, Market, Regulatory, and Barrier Mitigation. Part 3 has 1 layer, which is a continuation of the Solutions layer started in Part 2. Parts 1, 2, and 3 or the overall roadmap are shown in the figures below.

First, however, the following definitions provide a general description of each of the three layers used in the technology roadmapping process. Additional details related to the each of the component elements which appear on these roadmap layers are provided in Appendix F. Layer 1 consists of drivers. Drivers are underlying factors in the environment, such as business and regulatory forces and trends which motive some type or action or response. One example is a Zero Emission Vehicle (ZEV) mandate, which requires a certain percentage of vehicles sold after a specified deadline to be vehicles which produce no tailpipe emissions. This driver is a regulatory 
factor which motivates an action on the part of industry participants, such as manufacturers of electric vehicles and providers of electric vehicle charging stations to make those products available by the given deadline. Layer 2 consists of Gaps and Goals. Gaps represent the lack of something that a stakeholder feels is needed. For instance, if only $1 \%$ of vehicle currently sold are ZEVs and the eventual requirement is $10 \%$, there is a gap of $9 \%$. Similarly, a goal represents some type of outcome that is desired by particular stakeholders, but has not yet been reached. For example, one factor which may be related to the future deployment of more electric vehicle charging stations is rate and process restructuring concerning the prices and methods under which regulated utilities are currently allowed to sell electricity. So, the need for achieving that type of regulatory restructuring would be an important goal. This is similar to the concept of a Gap, but while Gaps often involve things that can be easily measured, such a $1 \%$ versus $10 \%$ vehicle sales, goals are generally more abstract, such a the need for a certain type of outcome. Layer 3 consists of Problem Characteristics and Barriers. Problem Characteristics are the factors involved a particular challenge, such factors that contribute to a certain Gap that currently exists. For example, there may be a need for significantly greater deployment of electric vehicle charging stations and infrastructure. However, until all the requirements are defined for these types of equipment and infrastructure, planning is difficult to perform. So, defining these types of requirements is an essential Problem Characteristic associated with this need. Similarly, Barriers consist of factors which are currently inhibiting the achievement of a specific outcome, such as a Gap or Goal. For example, there may be a need for reducing charging station cost, but the currently low level of adoption of charging stations means that economies of scale have not yet been achieve which can drive down costs. If this barrier is lifted and a solution can be found to deploy larger numbers of charging stations, then this can help meet the goal being blocked by the barrier, which is reduction of costs. On the roadmap, the Gap or Goal being blocked by a barrier is represented an arrow with a dashed line. Once the barrier is lifted, this Gap or Goal can be addressed. But, in order to lift that barrier, a solution is needed. Layer 4 addresses the issue of Solutions. Solutions address the challenges that underlie specific Problem Characteristics and Barriers. Solutions can consist of a variety of elements, including Business Development Processes, as well as Market, Regulatory, and Barrier Mitigation factors. For example, the reason economies of scale have not been achieved to drive down charging station cost may be related to factors such as lack of a public investment vision or plan of action for consistent deployment. So, Solutions that provide an investment vision for public charging stations, or Business Development Processes, such as the development of business-industry partnerships, can provide answers needed to address Problem Characteristics and lift Barriers. Each of these elements is shown in parts 1, 2, and 3 of the overall roadmap below.

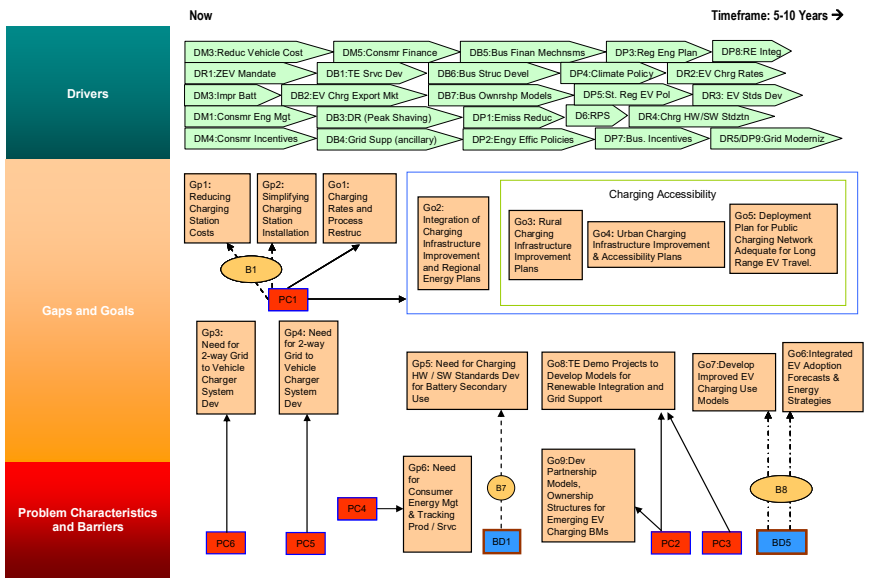

Fig. 6. Integrated TRM Model - Electric Vehicle Charging - Part 1

As previously mentioned, Part 1 of the overall roadmap represents the top 3 layers, which consists of Drivers, Gaps and Goals, as well as Problem Characteristics and Barriers. Part 2 of the roadmap then shows the next 2 layers, starting with a continuation of Problem Characteristics and Barriers, and then the initial portion of the Solutions layer. Part 2 is shown below.

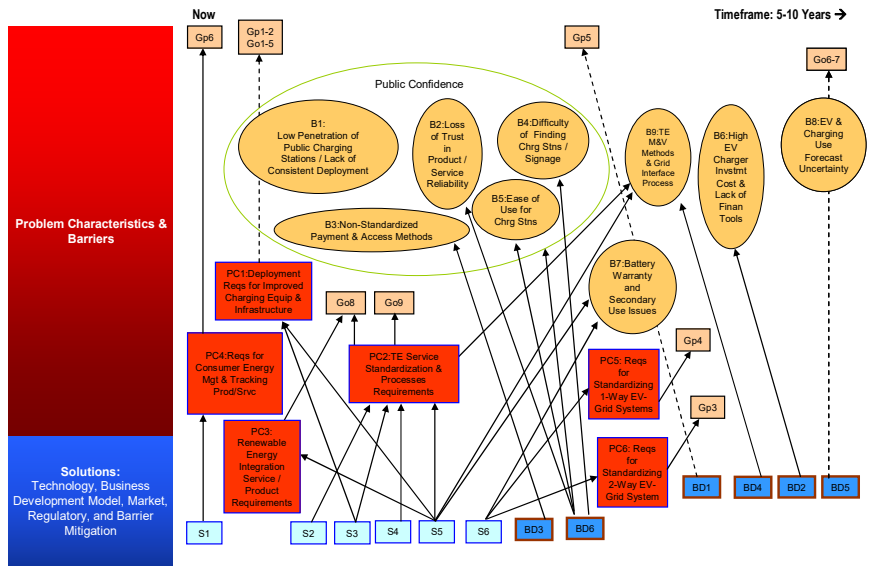

Fig. 7. Integrated TRM Model - Electric Vehicle Charging - Part 2

Part 2 of the general roadmap consists of the third and fourth layers, which starts with a continuation of the Problem Characteristics and Barriers layer and then begins the initial portion of the Solutions layer. Part 3 is then shown below. 

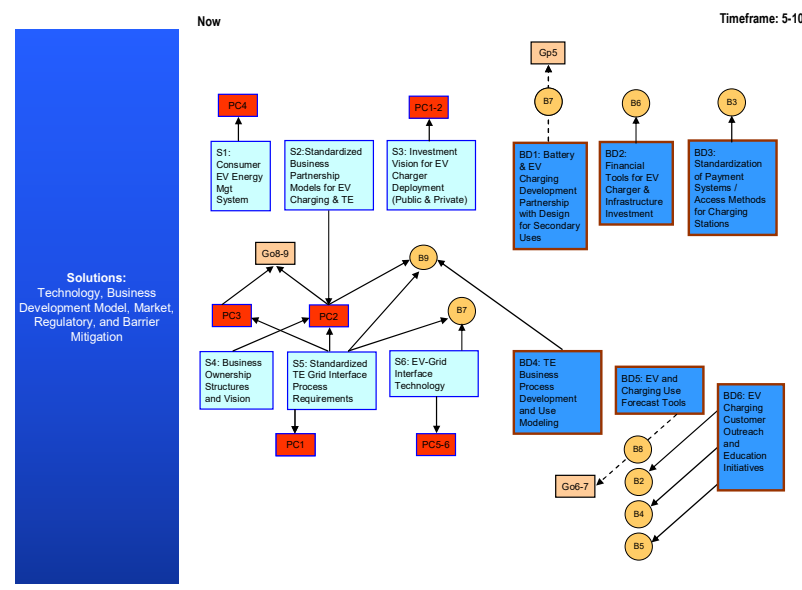

Fig. 8. Integrated TRM Model - Electric Vehicle Charging - Part 3

Part 3 of the general roadmap consists of the fourth layer, which began in Part 2. After showing each of these three parts, a number of important facts about the overall roadmap are discussed below, as well as some ways to improve the organization of the roadmap. To make it easier to focus on specific aspects of the roadmap over shorter time horizons, the roadmap is further broken into version A and version B for each of the of the 3 parts. Version A reorganizes the roadmap with a Business and Regulatory Organizational Focus, while version $\mathrm{B}$ reorganizes the roadmap with a Consumer and Market focus. Additional details about the organization of the roadmap are provided in the next section.

Several key pieces of information can be seen from the above figures. Key stakeholders include consumers, businesses, government organizations (GO), and nongovernment organization (NGO), and regulatory agencies. Decisions can then be made regarding whether to focus first on specific user segments among these stakeholders or on a combination of segments. Further decisions can be made regarding different options for ownership structure and primary profit mechanisms. Ownership structures include the possibility of consumers, utilities, or third-parties, such as energy service aggregators owning and/or operating EV charging equipment and services. Key profit mechanisms include the following: (1) Direct fees for vehicle charging and/or parking fees; (2) membership fees and fees for other bundled and premium services, such as internet access or auxiliary vehicle power hook-up fees; advertiser fees or fees for consumers to opt-out of advertisements; ancillary service fees, which provide essential services to utilities, such as voltage and frequency regulation; or energy efficiency optimization contracts and energy aggregation contracts, which allow a network operator to manage and optimize energy use over a grid or micro-grid. Other profit mechanism or combinations of mechanisms are also possible, but these were the main mechanisms identified through conversations with experts who participated in data gathering workshops for this study. Options for financing and distribution methods related to each business model were also considered that were appropriate for each of these cases. Methods for financing EV charging equipment purchase include rebates and tax credits for consumers, on-bill financing through utility companies, and third-party owned equipment with a service lease, or charging as a service models. Additional details about each of these points discussed above are provided in section 7.3.3, under the discussion of business models and in Appendix F of the full research study on which this article is based.

The overall roadmap shown in Parts 1, 2, and 3 summarizes a great deal of information about the technology, business, and regulatory landscape facing the electric vehicle charging industry. However, because it summarizes so many factors in one place, this can make the roadmap look cluttered and difficult to read. Therefore, to make it easier to focus on specific aspects of the roadmap, the follow sections breaks each of the 3 parts into 2 sections. Section A shows a Business and Regulatory focused version of the roadmap. Section B shows Consumer and Market focused version of the roadmap. Each of these are show below as parts 1 through 3 , sections A and B.
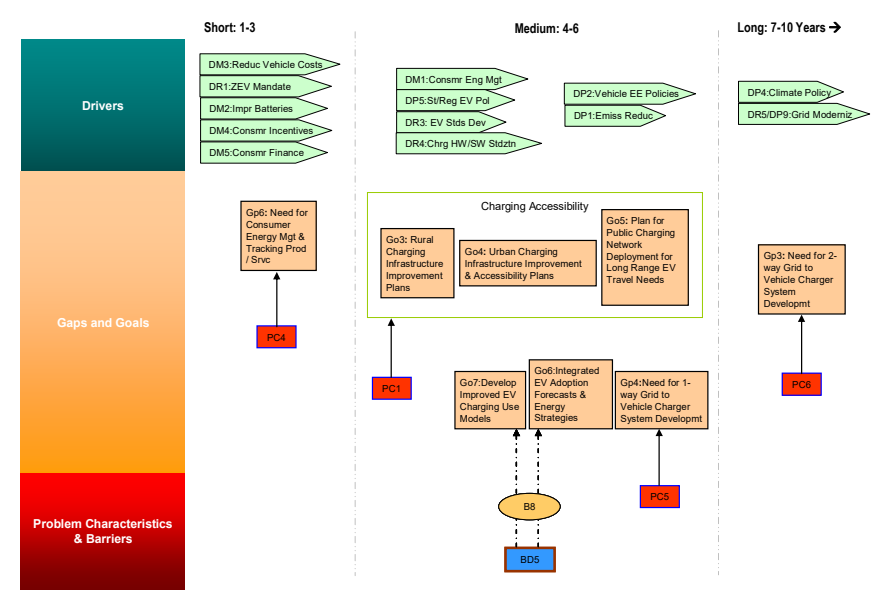

Fig. 9. Integrated TRM Model - Electric Vehicle Charging - Part 1a

Part 1a of the general roadmap consists of the third and fourth layers, which starts with a continuation of the Problem Characteristics and Barriers layer and then begins the initial portion of the Solutions layer. Part $1 \mathrm{~b}$ is then shown below.

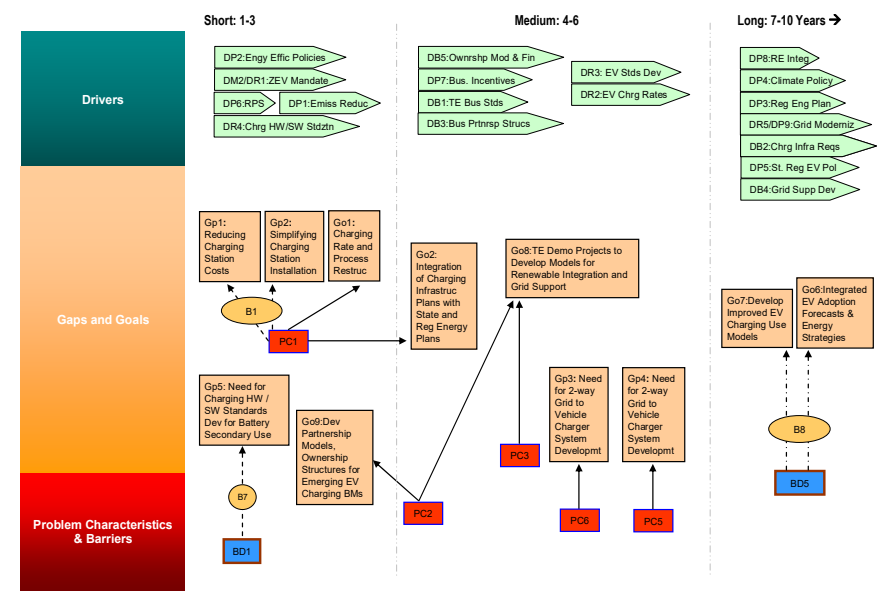

Fig. 10. Integrated TRM Model - Electric Vehicle Charging - Part 1b

Part $1 \mathrm{~b}$ of the general roadmap consists of the third and fourth layers, which starts with a continuation of the Problem Characteristics and Barriers layer and then begins the initial portion of the Solutions layer. Part 2a is then shown below. 

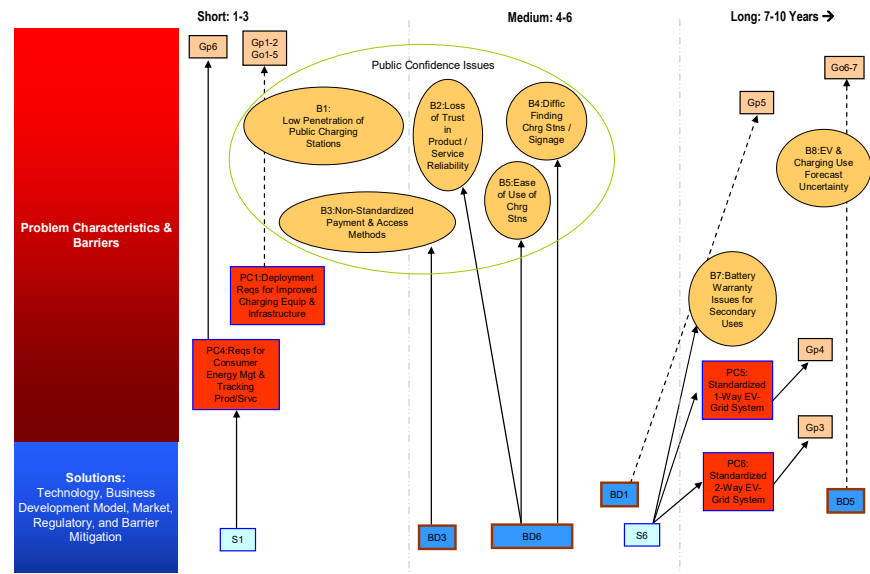

Fig. 11. Integrated TRM Model - Electric Vehicle Charging - Part 2a

Part 2a of the general roadmap consists of the third and fourth layers, which starts with a continuation of the Problem Characteristics and Barriers layer and then begins the initial portion of the Solutions layer. Part $2 b$ is then shown below.
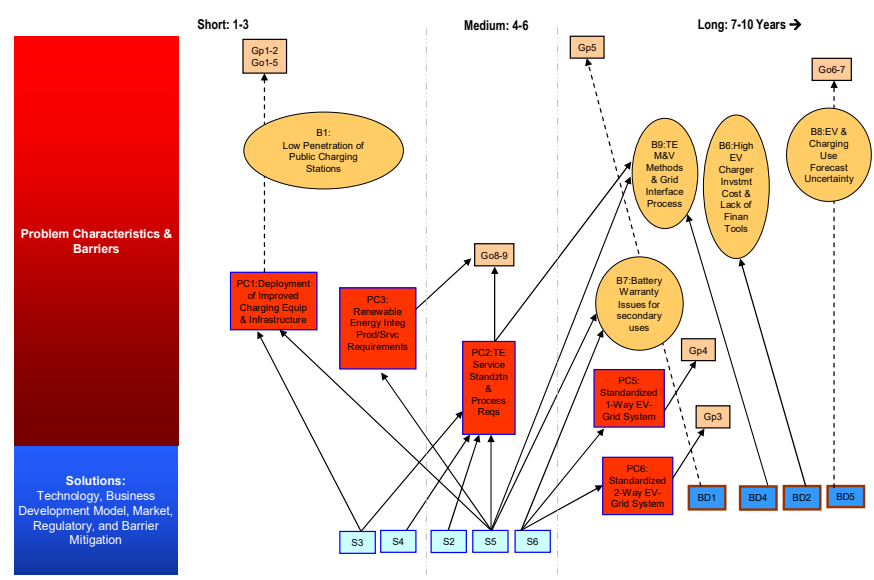

Fig. 12. Integrated TRM Model - Electric Vehicle Charging - Part 2b

Part $2 \mathrm{~b}$ of the general roadmap consists of the third and fourth layers, which starts with a continuation of the Problem Characteristics and Barriers layer and then begins the initial portion of the Solutions layer. Part 3a is then shown below.
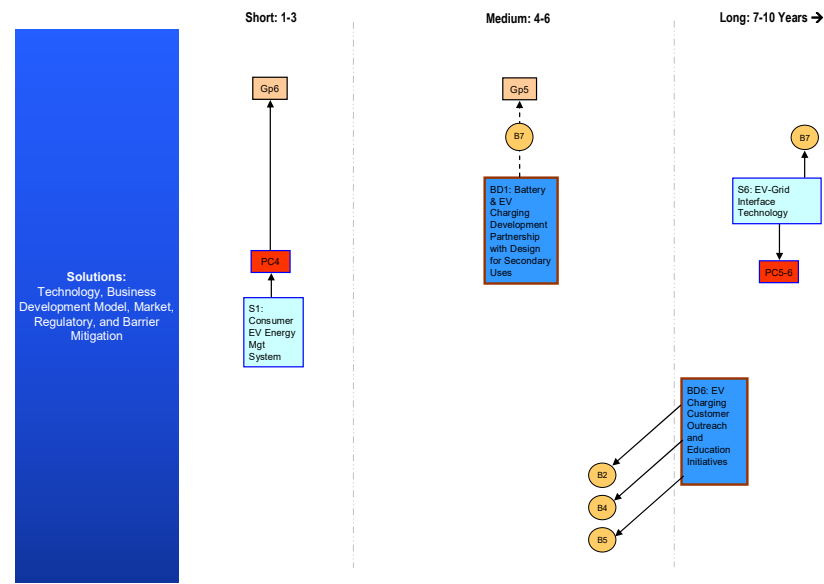

Fig. 13. Integrated TRM Model - Electric Vehicle Charging - Part 3a
Part 3a of the general roadmap consists of the third and fourth layers, which starts with a continuation of the Problem Characteristics and Barriers layer and then begins the initial portion of the Solutions layer. Part $3 b$ is then shown below.

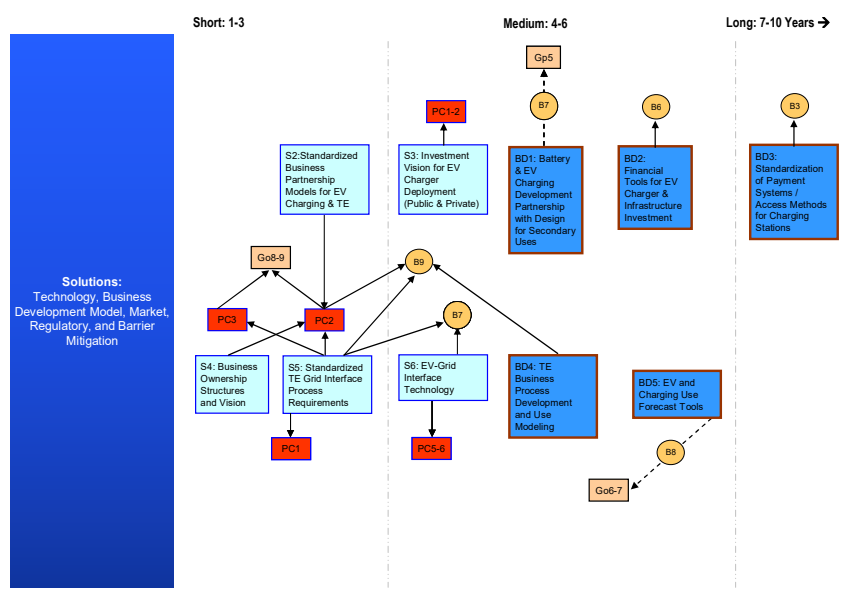

Fig. 14. Integrated TRM Model - Electric Vehicle Charging - Part 3b

Part $3 \mathrm{~b}$ of the general roadmap consists of the third and fourth layers, which starts with a continuation of the Problem Characteristics and Barriers layer and then begins the initial portion of the Solutions layer.

After constructing the many different roadmaps described in this chapter, analyzing their various parts, and organizing them into different topical areas, a key question that arises is how to best use these data and apply them to the industry environment. An important consideration for this is an analysis of what business models may be used to implement various aspects of the roadmaps that have been developed. To summarize the main business model challenges, expert input was gathered to create a taxonomy of business models appropriate for the issues discussed in the roadmap construction process. The models were divided into three main categories, based on the main business ownership structures: Investor-Owned structures (S1); Utility-Owned structures (S2); and Aggregator-Owned structures (S3). A series of business models variants were identified under each of these structures. A total of 31 business models were identified and assigned unique codes. These models are described in the next section.

\section{Business Model Alternatives}

To better understand how the data from this study can be used, several types of analysis were performed. As described in the previous section, a taxonomy of business models was constructed to summarize the main challenges related to implementation of various aspects of the roadmaps that were produced during the research. The business model taxonomy is show below. 


\begin{tabular}{|c|c|c|}
\hline Investor-Owned (S1) & Utility-Owned (S2) & $\begin{array}{l}\text { Third Party / Aggregator- } \\
\text { Owned (S3) }\end{array}$ \\
\hline 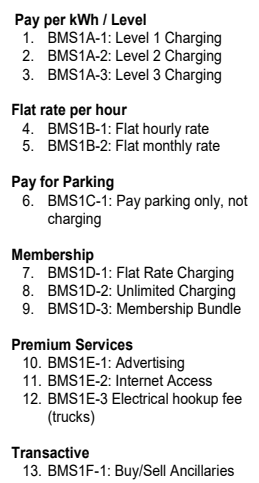 & 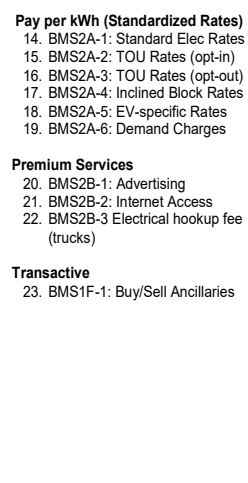 & $\begin{array}{l}\text { Agreements with EVSC owners } \\
\text { 24. BMSA }-1 \text { - L Level } 1 \text { Charging } \\
\text { 25. BMSA-2: Level 2 Charging } \\
\text { 26. BMS3A-3: Level } 3 \text { Charging } \\
\text { Agreements with Utilities } \\
\text { 27. BMS3B-1: Utility Contract } \\
\text { Energy Optimization Contracts } \\
\text { 28. BMS3C-1: Energy Contract } \\
\text { Transactive } \\
\text { 29. BMSBD-1: V2G } \\
\text { 30. BMS3D-2: V2B } \\
\text { 31. BMS3D-3: V2H }\end{array}$ \\
\hline
\end{tabular}

Fig. 15. Business Model Specifications

Three main categories of business models were identified based on the main business ownership structures: Structure 1 Investor-Owned models; Structure 2 - Utility-Owned models; and Structure 3 - Aggregator-Owned models (S3). A total of 31 business models variants were identified for each of these structures.

\section{CONCLUSIONS}

This research is intended to help improve the processes for envisioning and planning the introduction of emerging technologies into industries like the electrical utility sector. Historically, this industry has been slow to embrace modern information and communication technologies, due to a variety of factors, including relatively durable regulatory structures that have long been common in many parts of the world, as well as a difficulty creating products that have appropriate business models to meet regulatory and policy needs. A key goal of this research is to better integrate technology development with regulatory, policy, and business model development, to increase the likelihood of successful innovation. Within the utility industry, introduction of technologies related to grid modernization, or smart grid, have a particularly strong relevance to this research. However, development of a method that is useful in that area is also expected to have implications for improvements in many other industries, which have a variety of regulatory structures. This research performed a case study on the development of an integrated technology roadmapping process for electric vehicle charging. In addition to specific practical recommendations regarding the case study, this research provides a number of other important contributions to several fields of knowledge.

This research reviewed and analyzed many literature streams. It examined the current state of knowledge regarding smart grid technology and the emerging smart grid industry. In the process, it also examined the history of the U.S. electrical utility industry, as well as some of the relevant literature on utility economics. Integrated Resource Planning is another literature stream that was examined in the process of understanding how technology has been developed and deployed in this sector. Literature on energy policy and regulation was examined, as well as specific analysis regarding the policy landscape that has developed for the Pacific
Northwest region of the U.S. Closely tied to policy and regulatory issues, new frameworks, such as transactive energy structures were explored, and this in turn was specifically related to electric vehicle charging and vehicle-to-grid technology specifically. The technology roadmapping literature was also examined as a unifying concept for envisioning the technology development and deployment over time. Efforts specifically related to "smart grid roadmaps" were examined, and it was determined that few if any of the previous efforts in that literature stream would resemble those used in the technology roadmapping literature. Therefore, this research fills a gap by providing a technology roadmap on electric vehicle charging.

Furthermore, this research ties together important technology adoption concepts regarding "technology push" and "market pull" and offers several new concepts relevant to regulated industries, like electrical utilities. In addition to technology roadmaps balancing the technology push and market pull perspectives, it is proposed that regulated industries also have a significant "regulatory and policy push / pull" force that mediates between the technology push and market pull perspectives. Regulation can, for instance, distort market conditions, as well as place constraints on technology. Business models--which attempt to find a practical combination to solve the problem of competing technology, market, regulatory and policy forces--are affected by these simultaneous dynamics.

This research also examined relevant literature related to business models and tied it in to technology development business concept development, and analysis of industry forces. A set of general categories and characteristics were developed regarding the forces affecting the industry. A taxonomy of 31 business models were then develop and coded so that they could be easily distinguished and compared. These ideas were then connected to the technology roadmapping process. This provides an important resource for comparing elements of existing business models on the roadmap and helping stakeholders who wish to better understand this complex area. By providing a systematic framework for categorizing and comparing models as they relate to the roadmaps, it provides an excellent platform for adding further detail about models or as well as providing possible insights on the development of new models.

\section{REFERENCES}

[1] O. H. Bray and M. L. Garcia, Technology Roadmapping: The Integration of Strategic and Technology Planning for Competitiveness. Portland, OR: PICMET (Portland International Conference on Management of Engineering and Technology), 1997.

[2] R. Phaal, C. Farrukh, and D. Probert, T-Plan: The Fast-Start to Technology Roadmapping - Planning your Route to Success. Cambridge: University of Cambridge, Institute for Manufacturing, 2001.

[3] R. Phaal, C. J. P. Farrukh, and D. R. Probert, "Technology Roadmapping - A Planning Framework for Evolution and Revolution," Technological Forecasting and Social Change., vol. 71, p. 5, 2004.

[4] C. Holmes and M. Ferrill, "The application of Operation and Technology Roadmapping to aid Singaporean SMEs identify and select emerging technologies," Technological Forecasting and Social Change, vol. 72, pp. 349-357, 2005.

[5] A. Nauda and D. L. Hall, "Strategic technology planning--developing roadmaps for competitive advantage," in Portland International 
Conference on Management of Engineering and Technology, Portland, OR, 1991, pp. 745-748.

[6] R. N. Kostoff, "Systematic Acceleration of Radical Discovery and Innovation in Science and Technology," Technological Forecasting and Social Change, vol. 73, p. 923, 2006.

[7] M. Rinne, "Technology Roadmaps: Infrastructure for Innovation," Technological Forecasting and Social Change, vol. 71, p. 67, 2004.

[8] E. Lopez-Ortega, T. Concepcion, and S. Viloria, "Strategic Planning, Technology Roadmaps and Technology Intelligence: An Integrated Approach," presented at the PICMET (Portland Internation Conference for Management of Engineering \& Technology), Portland, Oregon, 2006.

[9] S. K. Kassicieh, S. T. Walsh, J. C. Cummings, P. J. M. Whorter, A. D. Romig, and W. D. Williams, "Factors Differentiating the Commercialization of Disruptive and Sustaining Technologies," IEEE transactions on engineering management /, vol. 49, p. 375, 2002.

[10] R. N. Kostoff, R. Boylan, and G. R. Simons, "Disruptive Technology Roadmaps," Technological Forecasting and Social Change, vol. 71, p. 141, 2004.

[11] S. T. Walsh, "Roadmapping a Disruptive Technology: A Case Study The Emerging Microsystems and Top-Down Nanosystems Industry," Technological Forecasting and Social Change, vol. 71, p. 161, 2004.

[12] S. T. Walsh and J. D. Linton, "Infrastructure for Emergent Industries Based on Discontinuous Innovations," Engineering Management Journal - Rolla, vol. 12, pp. 23-32, 2000.

[13] R. Zurcher and R. N. Kostoff, "Modeling Technology Roadmaps," The Journal of Technology Transfer, vol. 22, p. 73, 1997.

[14] B. A. Vojak and F. A. Chambers, "Roadmapping Disruptive Technical Threats and Opportunities in Complex, Technology-Based Subsystems: The SAILS Methodology," Technological Forecasting and Social Change, vol. 71, p. 121, 2004.

[15] J. L. Bower and C. M. Christensen, Disruptive Technologies: Catching the Wave. Boston, MA: Harvard Business School Publications, 1995.

[16] N. Gerdsri, "An Activity Guide for Technology Roadmapping," Technology Analysis and Strategic Management, vol. 22, pp. 229-242, 2010.

[17] M. Amer and T. U. Daim, "Application of Technology Roadmaps for Renewable Energy Sector," Technological Forecasting \& Social Change, vol. 77, pp. 1355-1370, 2010.

[18] H. Abe, T. Ashiki, A. Suzuki, F. Jinno, and H. Sakuma, "Integrating Business Modeling and Roadmapping Methods - The Innovation Support Technology (IST) Approach," Technological Forecasting and Social Change, vol. 76, pp. 80-90, 2009.

[19] D. Fenwick, T. U. Daim, and N. Gerdsri, "Value Driven Technology Road Mapping (VTRM) Process Integrating Decision Making and Marketing Tools: Case of Internet Security Technologies," Technological Forecasting and Social Change, vol. 76, pp. 1055-1077, 2009.

[20] A. M. Lamb, T. U. Daim, and S. Leavengood, "Wood Pellet Technology Roadmap," IEEE Transactions on Sustainable Energy, vol. 3, pp. 218-230, 2012.

[21] I. J. Petrick and A. E. Echols, "Technology Roadmapping in Review: A Tool for Making Sustainable New Product Development Decisions," Technological Forecasting and Social Change, vol. 71, p. 81, 2004.

[22] S. T. Walsh, R. L. Boylan, C. McDermott, and A. Paulson, "The Semiconductor Silicon Industry Roadmap: Epochs Driven by the Dynamics between Disruptive Technologies and Core Competencies," Technological Forecasting and Social Change, vol. 72, pp. 213-236, 2005.

[23] S. Lee, S. Kang, and Y. Park, "Technology Roadmapping for R\&D Planning: The Case of the Korean Parts and Materials Industry," Technovation, vol. 27, pp. 433-445, 2007.

[24] Y. Kajikawa, O. Usui, K. Hakata, Y. Yasunaga, and K. Matsushima, "Structure of Knowledge in the Science and Technology Roadmaps," Technological Forecasting Social Change Technological Forecasting and Social Change, vol. 75, pp. 1-11, 2008.

[25] R. W. Galvin, "A Practitioner's Update to Roadmapping: From Sustainable to Disruptive Technologies," Technological Forecasting and Social Change, vol. 71, pp. 91-103, 2004.

[26] G. L. Huffman, C. C. Lee, S. Rolander, and J. T. White, "A Summary of the EPA's Fuel Cell Program Dealing with the Environmental Life Cycle Assessment," Energy Sources, Part B: Economics, Planning and Policy, vol. 1, pp. 67-74, 2006.
[27] S. Lee and Y. Park, "Customization of Technology Roadmaps According to Roadmapping Purposes: Overall Process and Detailed Modules," Technological Forecasting and Social Change, vol. 72, p. 567, 2005.

[28] N. Gerdsri, "An Analytical Approach on Building a Technology Development Envelope (TDE) for Roadmapping of Emerging Technologies," 2005.

[29] N. Gerdsri and D. F. Kocaoglu, "Applying the Analytic Hierarchy Process (AHP) to Build a Strategic Framework for Technology Roadmapping," Mathematical and Computer Modelling, vol. 46, pp. 1071-1080, 2007.

[30] N. Gerdsri, R. S. Vatananan, and S. Dansamasatid, "Dealing with the Dynamics of Technology Roadmapping Implementation: A Case Study," Technological Forecasting and Social Change, vol. 76, pp. 5060, 2009.

[31] R. Phaal, C. Farrukh, and D. Probert, "Customizing Roadmapping," Research Technology Management, vol. 47, p. 26, 2004.

[32] T. Daim and T. Oliver, "Implementing Technology Roadmapping Process: A Case Study of a Government Agency," Technology Forecasting \& Social Change, vol. 75, pp. 687-720, 2008.

[33] K. R. Cowan and T. U. Daim, "Comparative Technological Roadmapping for Renewable Energy," Technology in Society, vol. 31, pp. 333-341, 2009.

[34] T. U. Daim, M. Amer, and R. Brenden, "Technology Roadmapping for Wind Energy: Case of the Pacific Northwest," Journal of Cleaner Production, vol. 20, pp. 27-37, 2012.

[35] T. Daim, T. Oliver, I. Iskin, and J. Kim, "Technology Roadmapping: An Efficient Tool for Driving Regional Technological Changes," in Sustainable Systems and Energy Management at the Regional Level, ed, 2012.

[36] T. Daim, D. Kocaoglu, N. Gerdsri, and I. Kockan, "Technology Development Envelope Approach for the Adoption of Future Powertrain Technologies: A Case Study on Ford Otosan Roadmapping Model," Journal of Transportation Systems Engineering and Information Technology, vol. 11, pp. 58-69, 2012.

[37] R. Phaal, N. T. M. H. Shehabuddeen, and P. Assakul, "Technology Roadmapping: Charting the Route Ahead for UK Road Transport," in Engineering Management Conference, 2002. IEMC '02. 2002 IEEE International, 2002, pp. 794-798 vol.2.

[38] R. Phaal, C. Farrukh, R. Mitchell, and D. Probert, "Starting-Up Roadmapping Fast," IEEE Engineering Management Review, vol. 31, pp. 54-60, 2003.

[39] O. Saritas and M. A. Oner, "Systemic Analysis of UK Foresight Results - Joint Application of Integrated Management Model and Roadmapping," Technological Forecasting and Social Change, vol. 71, p. 27,2004 .

[40] M. Dissel, R. Phaal, C. Farrukh, and D. Probert, "Value Roadmapping: A Structured Approach for Early Stage Technology Investment Decisions," presented at the PICMET 2006: Technology Management for the Global Future, Istanbul, Turkey, 2006.

[41] R. Phaal, E. O'Sullivan, M. Routley, S. Ford, and D. Probert, "A Framework for Mapping Industrial Emergence," Technological Forecasting \& Social Change, vol. 78, pp. 217-230, 2011.

[42] R. Phaal and G. Muller, "An Architectural Framework for Roadmapping: Towards Visual Strategy," Technological Forecasting and Social Change, vol. 76, pp. 39-49, 2009.

[43] V. Thorn, F. Hunt, R. Mitchell, D. Probert, and R. Phaal, "Internal Technology Valuation: Real World Issues," International Journal of Technology Management, vol. 53, pp. 149-160.

[44] H. Martin and T. U. Daim, "Technology Roadmap Development Process (TRDP) for the Service Sector: A Conceptual Framework," Technology in Society, vol. 34, pp. 94-105.

[45] G. Hamel, Leading the Revolution. Boston, MA: Harvard Business School Press, 2000.

[46] A. J. Slywotzky, Value Migration: How to Think Several Moves ahead of the Competition. Boston, MA: Harvard Business School Press, 1996.

[47] A. J. Slywotzky, The Art of Profitability. New York, NY: Warner Business Books, 2002.

[48] H. W. Chesbrough, Open Innovation: The New Imperative for Creating and Profiting from Technology. Boston, Mass.: Harvard Business School Press, 2003.

[49] M. E. Porter, On Competition. Boston, MA: Harvard Business School Pub., 2008. 
[50] M. E. Porter, The Five Competitive Forces that Shape Strategy. Boston, MA: Harvard Business School Publishing, 2008.

[51] H. Abe, T. Hirabayashi, F. Ishida, Y. Oku, M. Kado, and H. Sakuma, "Value Creation Framework of Business Modeling Methods for R\&D Outputs," presented at the PICMET (Portland International Conference for Management of Engineering and Technology), 2005.

[52] H. Abe, T. Hirabayashi, M. Kado, and H. Sakuma, "A New Framework of Business Modeling Methods for R\&D Outputs: Valuation and Communication Tools for Engineers, Managers, and Investors," presented at the PICMET (Portland International Conference for Management of Engineering and Technology), 2004.

[53] Y. Yasunaga, M. Watanabe, and M. Korenaga, "Application of Technology Roadmaps to Governmental Innovation Policy for Promoting Technology Convergence," Technological Forecasting and Social Change, vol. 76, pp. 61-79, 2009.

[54] Y. Zhou, "A Policy Dimension Required for Technology Roadmapping: Learning from the Development of Emerging Wind Energy Industry in China," presented at the PICMET 2011 Portland, OR, 2011.

[55] USDOE, "One Million Electric Vehicles By 2015: February Status Report," ed, 2011.

[56] NPCC, "Northwest Wind Integration Action Plan," NPCC (Northwest Power and Conservation Council), Portland, OR 2007.

[57] K. Dragoon, "Lowest Cost Balancing Resources," ed. Portland: NPCC (Northwest Power and Conservation Council), 2011.

[58] B. M. Nickell, "Wind Dispatchability and Storage - Interconnected Grid Perspective," EERE (Energy Efficiency \& Renewable Energy Department) 2009.

[59] Pike, "Annual Plug-in Electric Vehicle Sales to Cross the One Million Mark by 2015," Pike Research, Boulder Colorado2011.

[60] B. Halvorson, "Ten Percent Electric Vehicles By 2020? No Sweat, Utility CEO Says," Green Car Reports2011.

[61] C. Hussler, M. Tang, and F. Picard, "Taking the Ivory from the Tower to Coat the Economic World: Regional Strategies to make Science Useful," Technovation, vol. 30, pp. 508-518, 2010.

[62] I. S. Thukral, I. J. R. Von Ehr, S. Walsh, A. J. Groen, P. Van Der Sijde, and K. Akmaliah Adham, "Entrepreneurship, Emerging Technologies, Emerging Markets," International Small Business Journal, vol. 26, pp. 101-116, 2008.

[63] L. Karwoski-Magee and D. Ruben, "The Charrette: An Interdisciplinary Academic Tool," Design Principles and Practices: An International Journal, vol. 4, p. 11, 2010.

[64] W. Spencer and T. Seidel, "National Technology Roadmaps: The U.S. Semiconductor Experience " in 4th International Conference on SolidState and Integrated Circuit Technology, 1995.

[65] A. Diebold, "Overview of Metrology Requirements Based on the 1994 National Technology Roadmap for Semiconductors," in SEMATECH (IEEE/SEMI 1995 Advanced Semiconductor Manufacturing Conference and Workshop), Austin, TX, 1994.

[66] P. A. Koen, "Technology Maps: Choosing the Right Path," Engineering Management Journal - Rolla, vol. 9, pp. 7-11, 1997.

[67] R. N. Kostoff and R. R. Schaller, "Science and Technology Roadmaps," IEEE Transactions on Engineering Management, vol. 48, pp. 132-143, 2001.

[68] M. G. Kendall and B. B. Smith, "The Problem of Rankings," The Annals of Mathematical Statistics, vol. 10, pp. 275-287, 1989.

[69] H. A. Linstone and M. Turoff, The Delphi Method: Techniques and Applications. Reading, MA: Addison-Wesley Publishing Company, 1975.

[70] K. Brockhoff, "The Performance of Forcasting Groups in Computer Dialogue and Face-to-Face Discussion," in The Delphi Method: Techniques and Applications, H. Linstone and M. Turoff, Eds., ed Reading, MA: Addison- Wesley, 1975, pp. 291-321.

[71] T. L. Saaty, The Analytic Hierarchy Process: Planning, Priority Setting, Resource Allocation. New York; London: McGraw-Hill International Book Company, 1980.

[72] T. L. Saaty, "Axiomatic Foundation of the Analytic Hierarchy Process," Management Science, vol. 32, pp. 841-855, 1986.

[73] T. L. Saaty, Fundamentals of Decision Making and Priority Theory with the Analytic Hierarchy Process. Pittsburgh, PA: RWS Publications, 2000.

[74] J. L. Salmeron and I. Herrero, "An AHP-Based Methodology to Rank Critical Success Factors of Executive Information Systems," Computer Standards and Interfaces, vol. 28, pp. 1-12, 2005.
[75] E. Geisler, "The Metrics of Technology Evaluation: Where We Stand and Where We Should Go from Here," International Journal of Technology Management, vol. 24, pp. 341-374, 2002.

[76] D. J. Hammerstrom, J. M. Gephart, and R. W. A. Pacific Northwest National Laboratory, "Smart Technology Brings Power to the People," Power Engineering International, 14(10):45-46, vol. 14, 2006.

[77] P. Fox-Penner, "Fix Utilities Before they Need a Rescue," Harvard Business Review, vol. 87, 2009.

[78] P. Fox-Penner, Smart Power: Climate Change, the Smart Grid, and the Future of Electric Utilities: Island Press, 2010.

[79] EPRI, "The Green Grid: Energy Savings and Carbon Emissions Reductions Enabled by a Smart Grid," Electric Power Research Institute (EPRI) 2009

[80] R. J. Procter, "Smart Grid Inventory: A Report to the Oregon Public Utility Commission," Public Utility Commission of Oregon, Salem, OR2011.

[81] T. L. Friedman, Hot, Flat, and Crowded: Why we Need a Green Revolution -- And How it Can Renew America. New York: Farrar, Straus and Giroux, 2008.

[82] EPRI, "Estimating the Costs and Benefts of the Smart Grid: A Preliminary Estimate of the Investment Requirements and the Resultant Benefts of a Fully Functioning Smart Grid," Electric Power Research Institute (EPRI), Palo Alto, CA 2011.

[83] S. M. Amin and B. F. Wollenberg, "Toward a Smart Grid," IEEE Power \& Energy, vol. 4, p. 66, 2006.

[84] M. Rawson and J. Sugar, "Distributed Generation and Cogeneration Policy Roadmap for California," California Energy Commission, Sacramento, CA 2007.

[85] A. Chuang. (2011). California Utility Vision and Roadmap for the Smart Grid of 2020: Final Project Report. Available: http://bibpurl.oclc.org/web/45441http://www.energy.ca.gov/2011public ations/CEC-500-2011-034/CEC-500-2011-034.pdf

[86] CAISO, "Smart Grid Roadmap and Architecture," California Independent System Operator 2010.

[87] J. Houck and W. Rickerson, "The Sustainable Energy Utility (SEU) Model for Energy Service Delivery," The Bulletin of Science, Technology \& Society, vol. 29, pp. 95-107, 2009.

[88] A. J. O'Donnell, Soul of the Grid: A Cultural Biography of the California Independent System Operator. New York: Universe, 2003.

[89] CMU, "Smart Grid Maturity Model: Model Definition: A Framework for Smart Grid Transformation," Carnegie Mellon University (CMU), Fort Belvoir, VA 2010.

[90] W. S. Humphrey, Managing the Software Process. Reading, MA: Addison-Wesley, 1989.

[91] J. R. Persse, Implementing the Capability Maturity Model. New York: John Wiley \& Sons, 2001.

[92] Public Utilities Regulatory Policy Act of 1978: Report to Accompany S. 2114, 1978.

[93] X. Fang, S. Misra, G. Yue, and D. Yang, "Smart Grid - The New and Improved Power Grid: A Survey," IEEE Communications, 2011.

[94] CEC. (2010). CERTS Smart Grid Demonstration with Renewable Energy Integration. Available: http://www.energy.ca.gov/2010publications/CEC-500-2010-FS/CEC500-2010-FS-005.PDF

[95] ISSGC, "Illinois Statewide Smart Grid Collaborative: Collaborative Report," Illinois Statewide Smart Grid Collaborative 2010.

[96] ISGI, "Illinois Smart Grid Initiative: Summary of Smart Grid Bnefits and Issues," Illinois Smart Grid Initiative (ISGI) 2008.

[97] M. Olken, "A Smart Grid Partnership: International Efforts in Korea and Illinois," IEEE Power and Energy Magazine, vol. 9, pp. 4-6, 2012.

[98] Staff Recommendation to Use Oregon Electricity Regulators Assistance Project Funds from the American Recovery and Reinvestment Act of 2009 to Develop Commission Smart Grid Objectives for 2010-2014, OPUC Order No. 11-172, 2011.

[99] A. Brown and R. Satler, "Smart Grid Issues in State Law and Regulation," Galvin Electricity Initiative 2010.

[100] FERC, "Assessment of Demand Response \& Advanced Metering: Docket AD06-2-000," Federal Energy Regulatory Commission, Washington, D.C. 2008.

[101] R. W. Galvin, K. E. Yeager, and J. Stuller, Perfect Power: How the Microgrid Revolution Will Unleash Cleaner, Greener, and More Abundant Energy. New York: McGraw-Hill, 2009.

[102] NIST, "NIST Framework and Roadmap for Smart Grid Interoperability Standards, Release 1.0," National Institute of Standards and 
Technology, Office of the National Coordinator for Smart Grid Interoperability, Gaithersburg, MD2010 2010.

[103] Xcel, "Xcel Energy Smart Grid: A White Paper," Xcel Energy, Boulder, CO 2010.

[104] D. James, "Xcel Energy's Smart Grid," Proceeding of the Solar Conference, vol. 5, pp. 2859-2869, 2008.

[105] PSPI, "The Pecan Street Project: Working Group Recommendations," Pecan Street Project, Inc. (PSPI), Austin, TX2010.

[106] C. A. Smith, "The Pecan Street Project: Developing the Electric Utility System of the Future," University of Texas, Austin, TX, 2009.

[107] B. McCracken, K. Rábago, and M. E. Webber, Pecan Street Project Smart Grids and Austin's Energy Future. Austin, TX: University of Texas at Austin: Environmental Science Institute, 2010.

[108] Pacific Northwest Electric Power Planning and Conservation Act: Report to Accompany S. 885, 1979.

[109] NPCC, Restructuring of the Electric Utility Industry: Implications for the Goals of the Northwest Power Act. Portland, OR: Northwest Power Planning Council (NPCC), 1994.

[110] D. J. Duann, B. Chen, I. National Regulatory Research, and C. National Association of Regulatory Utility, A Survey of Recent State Initiatives on EPACT and FERC Order 636. Columbus, Ohio: National Regulatory Research Institute, 1994.

[111] K. Rose, R. E. Burns, and R. J. Graniere, Research Report: Summary of Key state Issues of FERC orders 888 and 889. Columbus, $\mathrm{OH}$ : National Regulatory Research Institute, 1997.

[112] K. W. Costello and R. E. Burns, Regional Transmission Organizations and the Coordination of Regional Electricity Markets: A Review of FERC Order 2000. Columbus, Ohio: National Regulatory Research Institute, 2000.

[113] EEI, A Summary of FERC's Standard Market Design Tariff NOPR. Washington, DC: Edison Electric Institute, 2002.

[114] Energy Policy Act of 2005, 2005.

[115] BPA, What is RTO West? Portland, OR: Bonneville Power Administration, 2000.

[116] M. R. Milligan. (2011). Western Interconnection Energy Imbalance Market: Status and Prospects. Available: http://purl.fdlp.gov/GPO/gpo16356

[117] ColumbiaGrid, "Intra-Hour Transaction Accelerator Platform: I-Tap," ColumbiaGrid2009.

[118] U. S. Congress, Energy Policy Act of 1992: Public Law 102-486-Oct. 24, 1992. Washington, DC: US Government Printing Office, 1992.

[119] H. Prem and N. Raghavan, "Building a Technology Roadmap in High Performance Computing in the Indian Context," presented at the PICMET 2005: A Unifying Discipline for Melting the Boundaries, Portland, OR, 2005.

[120] C. Wooster, "Encouraging Technology through Legislation: A Study of the Development of Cogeneration Facilities after the Enactment of the Public Utilities Regulatory Policies Act," 1988.

[121] R. Schaller, "Technological Innovation in the Semiconductor Industry: A Case Study of the International Technology Roadmap for Semiconductors (ITRS)," 2004

[122] C. Cleveland and C. Morris, Dictionary of Energy. Amsterdam; London: Elsevier, 2005.
[123] L. Karwoski-Magee and D. Ruben, "The Charrette: An Interdisciplinary Academic Tool," Design Principles and Practices: An International Journal, vol. 4, pp. 11-21, 2010.

[124] P. Newman and C. Leverhant, "The Fuzzy Front End - Technology Identification, Staging, and Maturation: Where the Battle is Often Lost Without Firing a Shot," presented at the PICMET, Portland, OR, 2001

[125] W. Kempton, "Automobiles: Designing the 21st century fleet," presented at the Seattle V2G Technical Symposium, Seattle, WA, 2005.

[126] R. Wells, R. Phaal, C. Farrukh, and D. Probert, "Technology Roadmapping for a Service Organization," Research technology management., vol. 47, p. 46, 2004.

[127] T. U. Daim, X. Wang, K. Cowan, and T. Shott, "Technology roadmap for smart electric vehicle-to-grid (V2G) of residential chargers," Journal of Innovation and Entrepreneurship, vol. 5, 2016.

[128] K. R. Cowan, T. U. Daim, E. "Understanding adoption of energy efficiency technologies: Applying behavioral theories of technology acceptance \&amp; use to understand the case of led lighting for commercial, residential, and industrial end-users," PICMET 2011, pp. $1-9,2011$.

[129] K. R. Cowan, R. R. Harmon, "The Market Case for Green Energy: A Multiple Perspectives Approach," PICMET 2007, pp. 2498-2508, 2007.

[130] G. Rouse and J. Kelly, "Electricity Reliability: Problems Progress and Policy Solutions," Galvin Electricity Initiative, 2011.

[131] J. Jenkins, J. Bauman, and J. Bissonette, "Renewable Energy Standard " Powering Oregon's Future 2007.

[132] B. Shively and J. Ferrare, Understanding today's electricity business. Laporte, CO: Enerdynamics, 2010.

[133] C. Cramer, Thomas Edison. San Diego, CA: Greenhaven Press, 2001.

[134] M. Filippini, "Are Municipal Electricity Distribution Utilities Natural Monopolies?," Annals of Public and Cooperative Economics, vol. 69, p. $157,1998$.

[135] S. Insull and W. E. Keily, Central Station Electric Service: Its Commercial Development and Economic Significance. Chicago, 1915.

[136] NSF, "Funds for Industrial R\&D as a Percent of Net Sales of Companies Performing Industrial R\&D in the United States," National Science Foundation (NSF), Washington, DC 2010.

[137] L. Fox, Enron: The Rise and Fall. Hoboken, N.J.: Wiley, 2003.

[138] J. Casazza, Understanding Electric Power Systems: An Overview of the Technology, the Marketplace, and Government Regulation: John Wiley \& Sons, 2010

[139] S. Coll, The Deal of the Century: The Break Up of AT\&T. New York: Atheneum, 1986

[140] A. Nauda and D. Hall, "Strategic Technology Planning - Developing Roadmaps for Competitive Advantage," presented at the PICMET 1991, Portland, OR, 1991.

[141] ODOE, "Summary of Oregon's RPS " Oregon Department of Energy 2007

[142] C. Willyard and C. McClees, "Motorola's Technology Roadmap Process," Research Management, pp. 13-19, 1987.

[143] C. Holmes and M. Ferrill, "The Application of Operation and Technology Roadmapping to Aid Singaporean SMEs Identify and Select Emerging Technologies," Technological Forecasting and Social Change, vol. 72, p. 349, 2005. 